\title{
Study on the off-season shallot seed storage using biological pesticides in Kretek district, Bantul regency, Yogyakarta special region
}

\author{
M Fajri ${ }^{*}$, Nurdeana Cahyaningrum, Irawati, and Heni Purwaningsih \\ Yogyakarta Assessment Institute for Agricultural Technology, Indonesia
}

\begin{abstract}
Farmers in the Samiran village use chemical pesticides to store their shallots. The purpose of this study was to examine the storage of shallot seeds from the off-season crops using biological pesticides. The research was conducted in March 2018 in the Ngudi Makmur farmer group. The research materials used were red onion varieties and biological pesticide of neem. The experimental design used was a completely randomized design with 3 factors with 2 replications. The factors were the type of biological pesticide (liquid and powder), storage treatment (hanging and in the basket), and the shallot varieties (Bimo, Crok Kuning, and Tajuk). The parameters observed were weight loss, damage level, growth capacity, and chemical composition. The results showed that the lowest weight loss was the storage of shallot off-season in the bucket with liquid pesticides on the Crok Kuning variety, while the high growth power test results were hanging. The treatment of biological pesticides can reduce the percentage of onion weight loss, while the use of powdered neem leaves can affect the weight loss, but it is not too high compared to the control. Hanging storage is better than basket storage because yield loss due to weight loss in basket is higher.
\end{abstract}

\section{Introduction}

Shallot is one of the national strategic agricultural commodities [1]. In shallot cultivation, the dose and type of fertilizer greatly affect plant fertility and tuber productivity [2]. The use of nitrogen fertilizers ranging from $50-100 \mathrm{~kg} / \mathrm{ha}$ can improve the quality of tubers and extend the shelf life of tubers [3]. Shallot production currently only reached $93.2 \%$ of the target $(1,498,659$ tons from the target of 1,608,766 tons). Improvement of shallot production performance needs to be continuously improved through the development of shallot area, regulation of cropping patterns, environmentally friendly pest control, use of appropriate production facilities, provision of postharvest facilities, especially storage warehouses. Shallots have a high strategic value because the price tends to fluctuate with different movement patterns between prices at the producer, parent market, and consumer levels. Prices at the producer level tend to be more volatile than prices in the home and consumer markets [4]. The price of shallots is closely related to the quality aspect. Good

*Corresponding author: fajri.litbangtan08@gmail.com 
and quality shallots can only be produced from good crop cultivation and good post-harvest handling. An important aspect in the cultivation and post-harvest attention of shallots is the provision of good and quality seeds. One important aspect is a good way of storing shallot seeds. After the shallots are harvested, the action that must be taken immediately is drying. This is to prevent tuber damage due to rot or disease.

Drying is done by drying methods as well as drying and storage technology [5]. The increase in shallot production needs to be continuously improved through the development of shallot areas, regulation of cropping patterns, environmentally friendly pest control, use of production facilities.

\section{Methods}

The study was conducted in Samiran village, Kretek sub-district, Bantul district in January - March 2018 (off-season) on the Ngudi Makmur farmer group. There are 3 storage treatment factors, namely storage method, onion varieties, and types of pesticides used. Storage is done in 2 ways, namely hanging, and stored in a besek (bucket). There are 3 varieties of shallots, namely Bima, Thailand, and Crok Kuning. There are 2 types of pesticides used, namely liquid biological pesticides and powdered biological pesticides of neem (Azadirachta Indica). The quality standard used is SNI-3159:2013 which contains the requirements for the quality of shallot seeds. Parameters observed were water content and physical and chemical characteristics of shallot bulbs. Observational data collected included tuber loss weight, number of deflated tubers, number of rotten tubers, number of sprouted tubers. A growth power test is carried out every 2 months.

\section{Results and Discussion}

Shallots can be cultivated using tubers as seeds. Onions used for seedlings are harvested longer, which is around 80-90 days after planting [6]. To meet the need for seeds in the shallot production center in Samiran village, farmers store them using chemical pesticides to extend the shelf life. The use of pesticides is felt by farmers to influence their health, especially in the respiratory tract, they experience shortness of breath due to the chemical pesticides used. To overcome these problems, it is necessary to introduce the use of biological pesticides which can extend the shelf life but do not cause health effects.

The drying of shallots carried out by farmers is by drying the shallots in under the sunlight. Shallots that have been tied in advance are arranged in such a way with the position of the onion bulbs on the bottom and the leaves on top. in such circumstances, the leaves will get direct sunlight and will experience drying first. The weakness of this drying method is that it requires a large enough open area and cannot be done perfectly in the rainy season. Drying in the rainy season can cause a decrease in quality due to bacterial infection.

In general, onion farmers store shallots by hanging shallot ties on bamboo above the kitchen fireplace, but the number of onions that can be stored this way is limited, depending on how large and how large the space above the kitchen fireplace is. For large quantities of onions, a wider storage space is needed with clean, dry, and not humid conditions with good ventilation and enough so that it can provide good air change in the room. A good temperature for storing shallots is $30-34^{\circ} \mathrm{C}$ and a humidity of $65-75 \%$.

Shallots must be stored in a specific environment if high product quality is to be expected. In addition, the treatment of shallots also affects the quality of the product. Shallot bulbs are said to be good if at harvest time the bulbs are old enough, not injured, and dry enough. Traditional storage is carried out with storage conditions at temperatures between $25-30^{\circ} \mathrm{C}$, RH $70-80 \%$ and air circulation (aeration) are quite good. Shallots are 
also stored in a non-traditional way, namely by refrigeration technology. The ideal conditions for this method are air with a temperature of $0^{\circ} \mathrm{C}$ and an $\mathrm{RH}$ between $60-70 \%$.

Storage that is commonly done is divided into traditional and non-traditional storage. Traditional storage, in stage I after harvest, shallots are dried in the sun with the intention of removing water contained in the outer skin and neck of the stem. In stage II, curing is carried out to help the development of the onion skin color to become shiny and attractive. Storage is carried out after stages I and II are completed, by hanging the tubers with the help of a parapet above the stove. The condition of the room is maintained at a temperature of $26-29^{\circ} \mathrm{C}$ with an $\mathrm{RH}$ of $70-80 \%$. Traditional storage can maintain the condition of onions for 6 months with a weight loss of about $25 \%$. This non-traditional storage is carried out by refrigeration. The main goal is to control the rate of transpiration, respiration, infection, and disease, and to maintain the product in the form that consumers are most interested. The weight loss of the seed tubers is also in line with the increase in storage temperature. Where the increase in weight loss also cannot be separated from the humidity (RH) of the environment in which the onion seed bulbs are stored [7]. In addition, the increase in weight loss of shallots occurred due to a higher increase in losses due to higher respiration.

Tabel 1. Data from the observation of the weight loss of shallots during storage by hanging treatment in the off-season

\begin{tabular}{|c|c|c|c|c|c|c|c|c|c|}
\hline \multirow{2}{*}{$\begin{array}{c}\text { Storage } \\
\text { Time }\end{array}$} & \multicolumn{9}{|c|}{ Varieties } \\
\cline { 2 - 11 } & \multicolumn{3}{|c|}{ Bima } & \multicolumn{3}{|c|}{ Yellow Crok } & \multicolumn{3}{c|}{ Thailand } \\
\hline & Liquid & Powder & Control & Liquid & Powder & Control & Liquid & Powder & Control \\
\hline Month 1 & 168 & 181 & 60 & 115 & 94 & 62 & 17 & 62 & 19 \\
\hline Month 2 & 407 & 418 & 153 & 197 & 172 & 97 & 82 & 129 & 47 \\
\hline Month 3 & 515 & 506 & 210 & 350 & 314 & 171 & 212 & 287 & 98 \\
\hline Month 4 & 583 & 567 & 253 & 424 & 395 & 187 & 270 & 381 & 133 \\
\hline Month 5 & 676 & 632 & 335 & 536 & 536 & 250 & 403 & 522 & 195 \\
\hline
\end{tabular}

Based on Table 1, the largest weight loss during storage occurred in the Bima variety, both in the use of powder and liquid pesticides, followed by the Crok Kuning and Thailand varieties. Meanwhile, the lowest weight loss was in the control of the Crok Kuning variety.

Table 2. Data on observation of weight loss of shallots during storage with besek (bucket) in the offseason

\begin{tabular}{|c|c|c|c|c|c|c|c|c|c|}
\hline \multirow{2}{*}{$\begin{array}{c}\text { Storage } \\
\text { Time }\end{array}$} & \multicolumn{9}{|c|}{ Varieties } \\
\cline { 2 - 11 } & \multicolumn{3}{|c|}{ Bima } & \multicolumn{3}{|c|}{ Yellow Crok } & \multicolumn{3}{c|}{ Thailand } \\
\hline & Liquid & Powder & Control & Liquid & Powder & Control & Liquid & Powder & Control \\
\hline Month 1 & 31 & 40 & 57 & 17 & 19 & 29 & 10 & 9 & 51 \\
\hline Month 2 & 78 & 80 & 134 & 28 & 34 & 53 & 42 & 38 & 93 \\
\hline Month 3 & 113 & 118 & 196 & 62 & 78 & 72 & 73 & 97 & 184 \\
\hline Month 4 & 122 & 129 & 198 & 79 & 88 & 91 & 95 & 127 & 198 \\
\hline Month 5 & 142 & 157 & 200 & 106 & 131 & 126 & 147 & 177 & 238 \\
\hline
\end{tabular}

Based on Table 2, the lowest weight loss rate is the storage of shallots off season in besek with liquid pesticides on the Crok Kuning variety. As for the lowest level of damage, namely the storage of shallots on the treatment season in besek without the application of pesticides (control) on the Thai variety.

Table 3 shows that most of the damage occurred due to deflation from the 1st month of storage to the 5 th month of storage, the higher the damage rate with the length of storage. The second level of damage due to tuber sprouting and rotting was almost non-existent in each variety. 
Tabel 3. Shallot storage damage rate on hanging treatment (off season)

\begin{tabular}{|c|c|c|c|c|c|c|c|c|c|c|}
\hline \multirow{3}{*}{\multicolumn{2}{|c|}{$\begin{array}{l}\text { Storage } \\
\text { Time }\end{array}$}} & \multicolumn{9}{|c|}{ Varieties } \\
\hline & & \multicolumn{3}{|c|}{ Bima } & \multicolumn{3}{|c|}{ Crok Kuning } & \multicolumn{3}{|c|}{ Thailand } \\
\hline & & Liq & Pow. & Cont. & Liq. & Pow. & Con. & Liq. & Pow. & Cont.. \\
\hline \multirow{3}{*}{ Month 1} & Deflated & 16 & 23 & 3 & 14 & 12 & 3 & 6 & 7 & 2 \\
\hline & Rotten & 2 & 1 & 0 & 0 & 0 & 0 & 0 & 0 & 0 \\
\hline & Sprout & 0 & 0 & 0 & 0 & 0 & 0 & 0 & 0 & 0 \\
\hline \multirow{3}{*}{ Month 2} & Deflated & 44 & 55 & 22 & 25 & 27 & 14 & 13 & 13 & 4 \\
\hline & Rotten & 1 & 0 & 0 & 0 & 0 & 0 & 0 & 0 & 0 \\
\hline & Sprout & 1 & 0 & 0 & 0 & 0 & 0 & 0 & 0 & 0 \\
\hline \multirow{3}{*}{ Month 3} & Deflated & 38 & 47 & 13 & 32 & 25 & 10 & 20 & 20 & 7 \\
\hline & Rotten & 0 & 0 & 0 & 0 & 0 & 0 & 0 & 0 & 0 \\
\hline & Sprout & 1 & 1 & 0 & 0 & 0 & 0 & 0 & 0 & 0 \\
\hline \multirow{3}{*}{ Month 4} & Deflated & 57 & 53 & 25 & 38 & 39 & 18 & 30 & 33 & 8 \\
\hline & Rotten & 0 & 0 & 0 & 0 & 0 & 0 & 0 & 0 & 0 \\
\hline & Sprout & 3 & 4 & 2 & 0 & 0 & 1 & 0 & 0 & 0 \\
\hline \multirow{3}{*}{ Month 5} & Deflated & 68 & 75 & 29 & 56 & 54 & 22 & 43 & 51 & 9 \\
\hline & Rotten & 0 & 0 & 0 & 0 & 0 & 0 & 0 & 0 & 0 \\
\hline & Sprout & 1 & 2 & 6 & 1 & 1 & 2 & 2 & 1 & 1 \\
\hline
\end{tabular}

Tabel 4. Shallot storage damage rate in besek (bucket) treatment (off season)

\begin{tabular}{|c|c|c|c|c|c|c|c|c|c|c|}
\hline \multirow{3}{*}{\multicolumn{2}{|c|}{ Storage Time }} & \multicolumn{9}{|c|}{ Varieties } \\
\hline & & \multicolumn{3}{|c|}{ Bima } & \multicolumn{3}{|c|}{ Crok Kuning } & \multicolumn{3}{|c|}{ Thailand } \\
\hline & & Liq & Pow. & Cont. & Liq. & Pow. & Con. & Liq. & Pow. & Cont.. \\
\hline \multirow{3}{*}{ Month 1} & Deflated & 9 & 8 & 4 & 3 & 3 & 3 & 1 & 2 & 2 \\
\hline & Rotten & 0 & 0 & 0 & 0 & 0 & 0 & 0 & 0 & 0 \\
\hline & Sprout & 0 & 0 & 0 & 0 & 0 & 0 & 0 & 0 & 0 \\
\hline \multirow{3}{*}{ Month 2} & Deflated & 15 & 16 & 4 & 4 & 5 & 2 & 3 & 3 & 3 \\
\hline & Rotten & 0 & 0 & 0 & 0 & 0 & 0 & 0 & 0 & 0 \\
\hline & Sprout & 0 & 0 & 0 & 0 & 0 & 0 & 0 & 0 & 0 \\
\hline \multirow{3}{*}{ Month 3} & Deflated & 12 & 13 & 2 & 6 & 8 & 1 & 3 & 7 & 3 \\
\hline & Rotten & 0 & 0 & 0 & 0 & 0 & 0 & 0 & 0 & 0 \\
\hline & Sprout & 0 & 0 & 0 & 0 & 0 & 0 & 0 & 0 & 0 \\
\hline \multirow{3}{*}{ Month 4} & Deflated & 17 & 20 & 6 & 8 & 11 & 0 & 4 & 11 & 2 \\
\hline & Rotten & 0 & 0 & 0 & 0 & 0 & 0 & 0 & 0 & 0 \\
\hline & Sprout & 4 & 4 & 0 & 0 & 0 & 0 & 1 & 1 & 0 \\
\hline \multirow{3}{*}{ Month 5} & Deflated & 13 & 16 & 0 & 7 & 10 & 0 & 7 & 11 & 1 \\
\hline & Rotten & 0 & 0 & 0 & 0 & 0 & 0 & 0 & 0 & 0 \\
\hline & Sprout & 3 & 1 & 0 & 1 & 0 & 0 & 1 & 1 & 0 \\
\hline
\end{tabular}

Based on the data in table 4, it can be concluded that the application of biological fertilizers can reduce the increase in weight loss of shallots and neem leaf biological fertilizers in the form of powder which can affect weight loss, which is not too high compared to the control. Hanging storage is better than basket storage because the weight loss in baskets is higher than hanging storage.

During storage, some tubers are deflated and shoots grow, this can happen because the temperature is too high. In the Bima variety, many shoots grew, and their buds fell, while the yellow Crok Kuning variety did not grow shoots and it was slightly deflated, the Thailand variety also did not grow shoots but many were deflated. 
Tabel 5. Shallot growth test results on hanging treatment (off season) at 2 months of storage

\begin{tabular}{|l|c|c|c|}
\hline \multirow{2}{*}{ Shallot Code } & \multicolumn{2}{|c|}{ Parameters } & \multirow{2}{*}{ \% growth power } \\
\cline { 2 - 3 } & Number of tubers & Number of growing tubers & 100 \\
\hline TA (1) & 10 & 10 & 100 \\
\hline TA (2) & 10 & 10 & 100 \\
\hline TB (1) & 10 & 10 & 100 \\
\hline TB (2) & 10 & 10 & 100 \\
\hline MA (1) & 10 & 10 & 100 \\
\hline MA (2) & 10 & 10 & 100 \\
\hline MB (1) & 10 & 10 & 100 \\
\hline MB (2) & 10 & 10 & 100 \\
\hline CRA (1) & 10 & 10 & 100 \\
\hline CRA (2) & 10 & 9 & 100 \\
\hline CRB (1) & 10 & 9 & 100 \\
\hline CRB (2) & 10 & 10 & 100 \\
\hline \multicolumn{2}{|c|}{ CONTROL } & & 100 \\
\hline CROK K & 10 & 10 & 100 \\
\hline THAILAND & 10 & 10 & 100 \\
\hline BIMA & 10 & 10 & \\
\hline
\end{tabular}

Description:

$\mathrm{A}=$ biopesticide powder

$\mathrm{B}=$ biopesticide liquid

$\mathrm{T}=$ Thailand

$\mathrm{M}=\mathrm{Bima}$

$\mathrm{CK}=$ Crok Kuning

Tabel 6. Results of shallot growth test results in besek(bucket) (off season) for 2 months of storage

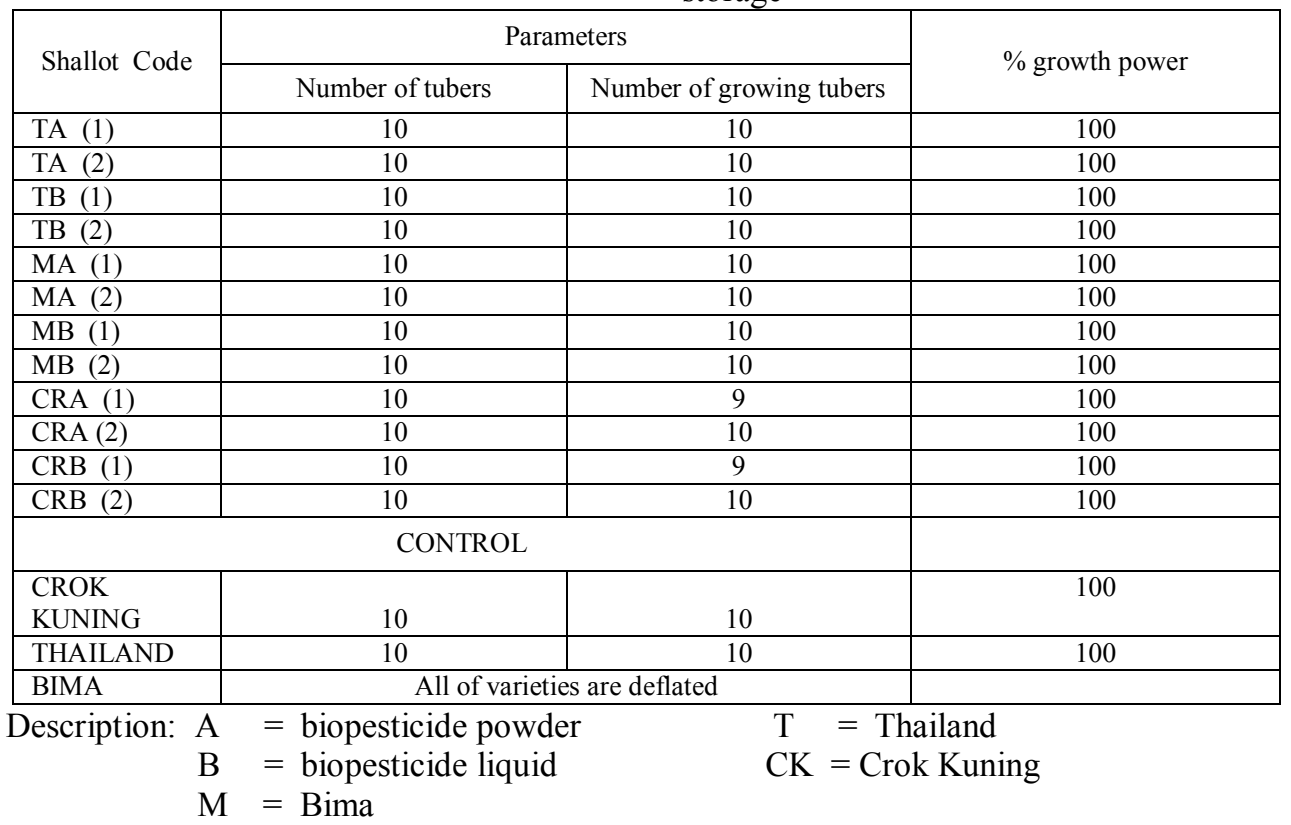

Shallot tubers experienced a decrease in quality during 12 weeks of storage, but the strength index and germination speed after storage period can still be maintained. [8]. Cultivar Bima showed the best adaptation in terms of quality, i.e., bulb hardness. In addition, this cultivar was the most adaptive to the rainy season (off-season) [9]. The growth potential of shallots after storage is still good. The rate of growth and germination of seeds has decreased from its potential [10]. The shallot bulbs that singly stored had a 
significant effect on the diseases caused by Peronospora destructor, Alternaria poor, and Fusarium wilt with low percentage category [11].

Changes in chemical composition during storage are known by analyzing at the beginning and end of storage, which can be seen in Table 7 and Table 8.

Tabel 7. Results of chemical composition analysis at the beginning of storage

\begin{tabular}{|l|c|c|c|c|c|c|}
\hline \multirow{2}{*}{$\begin{array}{l}\text { Chemical } \\
\text { composition }\end{array}$} & \multicolumn{6}{|c|}{ Varieties } \\
\cline { 2 - 7 } & \multicolumn{2}{|c|}{ Bima } & \multicolumn{2}{c|}{ Crok Kuning } & \multicolumn{2}{c|}{ Thailand } \\
\cline { 2 - 7 } & Powder & Liquid & Powder & Liquid & Powder & Liquid \\
\hline Water & 78.56 & 81.31 & 79.55 & 81.31 & 81.24 & 81.20 \\
\hline Ash & 1.51 & 1.06 & 1.05 & 1.06 & 1.15 & 0.96 \\
\hline Protein & 3.635 & 3.65 & 6.535 & 3.65 & 2.605 & 2.84 \\
\hline Lipid & 0.475 & 0.305 & 0.52 & 0.305 & 0.27 & 0.32 \\
\hline Crude fiber & 8.31 & 7.69 & 6.54 & 7.69 & 5.79 & 6.08 \\
\hline Carbohydrat & 7.73 & 6.08 & 9.15 & 6.08 & 8.96 & 8.62 \\
\hline Energy & 49.58 & 41.37 & 52.42 & 41.37 & 48.06 & 48.09 \\
\hline Antioxidant & 82.47 & 82.18 & 80.3515 & 82.18 & 84.37 & 84.3 \\
\hline Vitamin A & 230.07 & 182.4 & 123.32 & 182.4 & 127.61 & 164.52 \\
\hline Vitamin C & 282.08 & 296.62 & 429.755 & 296.62 & 309.485 & 286.93 \\
\hline
\end{tabular}

The results of the analysis of the composition at the beginning of storage showed some differences in the amount of nutrient content of several varieties used in the study. However, the difference is not significant. The initial moisture content of storage was lowered to below $86 \%$ (standard moisture content of shallot storage). The highest carbohydrate content is found in the Crok Kuning variety, as well as protein content and fat content. The highest crude fiber content was found in the Bima variety, followed by the yellow Crok and Thailand. The highest antioxidant content was found in the Thai variety, followed by the yellow Crok and Bima. The highest calories were found in the yellow Crok variety, followed by Thailand and Bima. The highest vitamin A content was found in the Bima variety, followed by CrokKuning and Thailand. Meanwhile, the highest Vitamin $\mathrm{C}$ was found in Crok Kuning, followed by Thailand and Bima.The results of the chemical composition analysis at the end of storage are as shown in Table 8 .

Table 8. Result of chemical composition analysis at the end of storage

\begin{tabular}{|l|c|c|c|c|c|c|}
\hline \multirow{2}{*}{ Chemical composition } & \multicolumn{7}{|c|}{ Varieties } \\
\cline { 2 - 7 } & \multicolumn{2}{|c|}{ Bima } & \multicolumn{2}{c|}{ Crok kuning } & \multicolumn{2}{c|}{ Thailand } \\
\cline { 2 - 7 } & Powder & Liquid & Powder & Liquid & Powder & Liquid \\
\hline Water & 78.52 & 78.5 & 81.64 & 80.99 & 84.19 & 83.76 \\
\hline Ash & 1.55 & 1.72 & 1.19 & 1.25 & 1.34 & 1.13 \\
\hline Protein & 2.86 & 3.57 & 3.49 & 2.53 & 3.69 & 3.39 \\
\hline Lipid & 1.04 & 0.75 & 0.67 & 0.94 & 0.475 & 0.525 \\
\hline Crude fiber & 5.75 & 7.87 & 6.135 & 7.615 & 7.56 & 5.55 \\
\hline Carbohydrat & 10.29 & 7.29 & 6.875 & 6.745 & 2.745 & 5.645 \\
\hline Energy & 61.21 & 51.38 & 47.48 & 44.64 & 30.65 & 40.99 \\
\hline Antioxidant & 90.86 & 89.16 & 91.34 & 91.34 & 86.48 & 90.35 \\
\hline Vitamin A & 266.57 & 236.44 & 142.57 & 130.71 & 284.40 & 168.91 \\
\hline Vitamin C & 278.31 & 382.21 & 130.71 & 233.79 & 308.58 & 205.24 \\
\hline
\end{tabular}

Based on Table 8, the results of the analysis of the chemical composition of shallots at the end of storage showed a decrease in the nutritional content. This is caused by the 
process of denaturation or damage during storage. However, there are nutrients that have increased due to the ongoing metabolic process in shallots during storage. Based on the results of the analysis, the application of pesticides, both powder, and liquid, had no significant effect on the chemical composition of shallots after storage.

\section{Conclusion}

The lowest weight loss was the storage of shallot off-season in the baskets with liquid pesticides on the Crok Kuning variety, while the high growth power test results were hanging. The treatment of biological pesticides can reduce the percentage of onion weight loss, while the use of powdered neem leaves can affect the weight loss, but it is not too high compared to the control. Hanging storage is better than basket storage because the weight loss results in the basket are higher than hanging storage.

\section{References}

1. L. Rahmadona, A. Fariyanti, and B., J. Hortik. Indones. 8, 128 (2017).

2. R. Remona, E. Trinurani Sofyan, B. Joy, R. Sudirja, A. Yuniarti, and J. Sauman Hamdani, Am. J. Biol. Environ. Stat. 6, 50 (2020).

3. S. K. Woldetsadik and T. S. Workneh, African J. Agric. Res. 5, 3342 (2010).

4. Sahara, M. H. Utari, and Z. Azijah, Bul. Ilm. Litbang Perdagang. 13, 309 (2019).

5. D. P. Agriawati, H. F. Purba, and T. Purba, 5, 253 (2021).

6. B. Baswarsiati and C. Tafakresnanto, Agrika 13, 147 (2019).

7. Rustini , S dan Prayudi, B. 2011. "Teknologi Produksi Benih Bawang Merah Varietas Bima Brebes.” In Risalah Hasil Pengkajian Inovasi Hortikultura Di Jawa Tengah. JawaTengah (ID). Balai Pengkajian Teknologi Pertanian Jawa Tengah.,.

8. R. H. Sri Lestari, E. Sulistyaningsih, and A. Purwantoro, Ilmu Pertan. (Agricultural Sci. 3, 117 (2019).

9. A. Firmansyah and A. Bhermana, Ilmu Pertan. (Agricultural Sci. 4, 110 (2019).

10.S. Megawati, Pardono, and E. Triharyanto, IOP Conf. Ser. Earth Environ. Sci. 466, (2020).

11. 1. R. Tarigan, F. Manik, and S. Barus, JERAMI Indones. J. Crop Sci. 1, 8 (2019). 